\title{
Residual Effects of Long-term Biosolids Application on Concentrations of Carbon, Cadmium, Copper, Lead and Zinc in Soils from Two Regions of the United States
}

\author{
Eton E. Codling ${ }^{a}$, Ngowari Jaja ${ }^{b}$, Wale Adewunmic, and Gregory K. Evanylo ${ }^{d}$ \\ aUSDA-ARS, Adaptive Cropping Systems Laboratory, Beltsville, MD, USA; boak Ridge Institute for Science and \\ Education (ORISE), Oak Ridge, TN, USA; 'Binomial Associates, LLC, Bridgewater, NJ, USA; ${ }^{d}$ Department of Crop and \\ Environmental Science, Virginia Polytechnic Institute and State University, Blacksburg, VA, USA
}

\begin{abstract}
Biosolids are used to improve soil physical and chemical properties. Analysis of biosolids-amended soils from multiple regions of United States using consistent analytical methods is lacking. This Study determined long-term biosolids application on soil $\mathrm{pH}$, electrical conductivity (EC), carbon, cadmium, copper, lead, and zinc concentrations in soils from two regions in United States. At one region, little difference was observed in $\mathrm{pH}$ and EC between biosolids-amended surface soils and control, the second region ranged from 5.46 to 7.87 and 50.2 to $402 \mu \mathrm{S} \mathrm{cm}^{-1}$ respectively. Trace metal levels at this region ranged from 0.76 to $3.79,8.7$ to $54.1,15.2$ to 53.9 , and 26 to $207 \mathrm{mg} \mathrm{kg}^{-1}$ for Cadmium, Copper, lead and Zinc respectively; with its carbon levels ranging from 14.5 to $90.0 \mathrm{~g} \mathrm{~kg}^{-1}$. Metal levels were within the standards for residential occupation with the 40 Code of Federal Regulations (CFR) Part 503 and should not affect soil and groundwater quality.
\end{abstract}

\section{ARTICLE HISTORY}

Received 2 October 2020

Accepted 3 December 2020

\section{KEYWORDS}

Biosolids; carbon; trace metals

\section{Introduction}

Biosolids consist of mainly organic material resulting from stabilized primary and secondary sludge from wastewater treatment facilities by the process of both aerobic and anaerobic digestions like lime stabilization, thermal drying, composting, etc. Characteristic of biosolids vary depending on the process used for pathogen reduction (Brown et al., 2003; Hirpassa and Codling 2019; Wang et al. 2008). Biosolids are rich in plant nutrients and have been used as soil amendments to improve soil physical and chemical properties (Hirpassa and Codling 2019). Biosolids have also been shown to improve soil fertility and increase soil organic carbon (Brown et al. 2011; Granato et al. 2004; Li and Evanylo 2013; Sharma et al. 2017; Wuest and Reardon 2016; Zhai et al. 2014). Wijesekara et al. (2017) observed a $45 \%$ increase in soil total organic carbon in the surface layer $(0-15 \mathrm{~cm})$ of a biosolidsamended soil, attributing the increase to a direct contribution from residual carbon from the biosolids application and to increased biomass production of crops grown on the amended soil. Biosolids may also increase water infiltration and reduce erosion due to the hydrological effects of biosolids on runoff (Moffet et al. 2005; Zartman et al. 2012). Although biosolids application is an effective method of supplying plant nutrients, increasing soil organic carbon, and reducing runoff and erosion, it can also increase heavy metal concentrations in soils (Codling 2014; Mossa et al. 2020). Barbarick, Ippolito, and Wesfall (1998) reported that after five applications of biosolids, significant accumulation of trace elements was observed in the plow layer but not (except for $\mathrm{Zn}$ ) in the subsoil. Sloan, Dowdy, and 
Dolan (1998) observed that Cadmium (Cd), Chromium (Cr), Copper (Cu), Nickle (Ni), lead (Pb), and Zinc (Zn) concentrations in biosolids-amended soil were much higher than in the control. However, some other studies reported that long-term biosolids application did not increase concentrations of heavy metals to toxic levels (Gaskin et al. 2003; Sukkariyah et al. 2005a) and even after a 17 year period of biosolid applications, there was negligible movement of trace metals through the soil profile and consequently little risk of contamination of ground water at the studied site (Sukkariyah et al. 2005b). Even a study on locations of high rates of biosolids observed results suggesting that the long-term application of biosolids at high loading rates does not result in trace metal pollution of groundwater (Oladeji et al. 2012). The degree of heavy metal accumulation in biosolids-amended soil depends on the biosolids source and on soil properties. For example, biosolids from sanitary wastewater generally have lower levels of heavy metals compared to those contaminated by industrial waste (Silveira, Alleoni, and Guilherme 2003). However, in the United States, industrial waste is omitted from wastewater treatment plant (WWTP) for the production of biosolids by the Wastewater Pretreatment Regulations; noting that a wastewater treatment plant is a facility in which a combination of various processes (e.g., physical, chemical and biological) are used to treat industrial wastewater and remove pollutants (Hreiz, Latifi, and Roche 2015). The purpose of this study was to determine residual concentrations of carbon and heavy metals in long-term biosolids-amended soils from two regions in the United States, using the same extracting methods for all samples.

\section{Materials and methods}

\section{Soil collection}

Soils for this study were collected from several sites in the states of New Jersey and Virginia with histories of biosolids application.

In the spring of 2017, soil samples were collected from agricultural fields and reclaimed lands at six locations in New Jersey: Hunterdon, Salem, Gloucester-E, Gloucester-H, Middlesex and Monmouth. Soil properties and histories of biosolids application as well as the cropping history of the fields are presented in Table 1. Soil samples were collected from two depths $(0-15$ and $15-30 \mathrm{~cm})$ from each field/site. Each sample was a composite of six 1.5 -cm diameter cores.

In the fall of 2017, soil samples were collected from two locations in Virginia with histories of biosolids application. Location I, on a Fauquier silt loam, was at the Northern Piedmont Research Station in Orange, where an experiment had been established in 1999 with a complete block design and four replications, where each plot was $3.6 \mathrm{~m}$ wide and $7.5 \mathrm{~m}$ long. Treatments sampled for the current study were a control (commercial fertilizer), biosolids compost $\left(4.48-11.21 \mathrm{Mg} \mathrm{ha}{ }^{-1}\right.$ ), and biosolids compost (4.48-11.21 $\mathrm{Mg} \mathrm{ha}^{-1}$ ) + fertilizer (Table 2). Location II was in Charles City County on a Pamunkey sandy loam soil. Each plot was approximately 36 by $15 \mathrm{~m}$ in size. Treatments were 0 (control), 14, 43, 70 and $98 \mathrm{Mg} \mathrm{ha}^{-1}$ anaerobically digested biosolids (Table 2). Experimental methods were as described by Li and Evanylo (2013) for Locations I and II, (Evanylo et al. 2008; Spargo, Evanylo, and Alley 2006; for Location I), and Daniels et al. (2001) for Location II.

\section{Soil analysis}

The soil was air-dried, passed through a $2-\mathrm{mm}$ mesh sieve and stored for analyses. Soil pH was measured in a 1:1 soil: deionized water suspension after $1 \mathrm{~h}$ of equilibration. Electrical conductivity (EC) was determined in a 1:2 soil: deionized water solution after $1 \mathrm{~h}$ of equilibration. For total carbon (C) determination, soil samples were ground using a mortar and pestle to $<0.25 \mathrm{~mm}$ and analyzed using a rapid carbon sulfur analyzer (Elementar, Hanau, Germany) for which $30 \mathrm{mg}$ of ground soil and $30 \mathrm{mg}$ of conditioner (Tungsten VI and Wolfram VI oxides) were wrapped in tin foil prior to measurement. The detection limit of the instrument was $0.01 \mathrm{mg} \mathrm{C}$, corresponding to a $\mathrm{C}$ concentration of $0.03 \%$ in a $30-\mathrm{mg}$ sample (Codling and Eickhoff 2012). Total elemental composition of the soil 


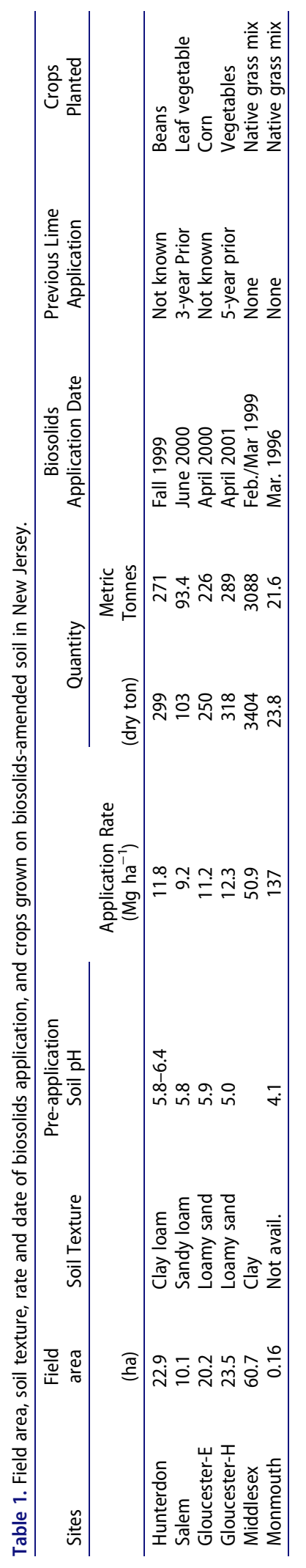


Table 2. Soil texture, rate and dates of biosolids application, and crops grown on biosolids-amended soils at two locations in Virginia.

\begin{tabular}{|c|c|c|c|c|}
\hline Location & Soil Series & Treatments & Frequency & Crops History \\
\hline $\begin{array}{l}\text { Location } \\
\text { I }\end{array}$ & $\begin{array}{l}\text { Fauquier silty clay } \\
\text { loam }\end{array}$ & $\begin{array}{l}\text { 1. Fertilized control } \\
\text { 2. Biosolids compost at the } \\
\text { agronomic } \\
\mathrm{N} \text { rate of } 4.48-11.21 \mathrm{Mg} \mathrm{ha}^{-1}(\mathrm{BC}) \\
\text { 3. Biosolids compost at the } \\
\text { agronomic } \\
\mathrm{N} \text { rate of } 4.48-11.21 \mathrm{Mg} \mathrm{ha}^{-1} \\
+ \text { fertilizer } \\
\text { to meet crop needs (BCF) }\end{array}$ & $\begin{array}{l}2000,2002 \\
2003 \\
2004\end{array}$ & $\begin{array}{l}\text { The crop included pumpkin in } 2000 \text {, } \\
\text { Sweet corn } 2001 \text {, and bell pepper in } \\
2002 \text {. } \\
\text { Corn was grown in } 2003-2004 \text {, and } \\
\text { soybean was grown in } 2005 \text {. Cereal rye } \\
\text { was } \\
\text { planted in the autumn } 2000-2005 \text { as } \\
\text { winter } \\
\text { cover crop. Tall fescue was planted in } \\
2006-2011 \text {. }\end{array}$ \\
\hline $\begin{array}{l}\text { Location } \\
\quad \text { II }\end{array}$ & $\begin{array}{l}\text { Pamunkey sandy } \\
\text { loam }\end{array}$ & $\begin{array}{l}0 \text { (fertilized control), 14, 42, 70, } \\
\text { and } 98 \mathrm{Mg} \mathrm{ha}^{-1} \text { anaerobically } \\
\text { digested biosolids }\end{array}$ & 1996 & $\begin{array}{l}\text { Crops included corn 1996, wheat in fall } \\
\text { 1996, } \\
\text { Soybean 1997, and cotton in } 1998 \text { until } \\
2017 .\end{array}$ \\
\hline
\end{tabular}

From Li and Evanylo (2012).

was determined using Aqua Regia digestion (McGrath and Cunliffe 1985). Briefly, $5 \mathrm{ml}$ of concentrated nitric acid $\left(\mathrm{HNO}_{3}\right)$ and $15 \mathrm{ml}$ of concentrated hydrochloric acid $(\mathrm{HCl})$ were added to $10 \mathrm{~g}$ of soil and refluxed for $2 \mathrm{~h}$. The mixture was heated to dryness, $20 \mathrm{ml} 3 \mathrm{~N} \mathrm{HCl}$ was added and heated for an additional $2 \mathrm{~h}$, then filtered, and the filtrate was brought to a volume of $50 \mathrm{ml}$ with $0.1 \mathrm{~N} \mathrm{HCl}$. Elemental concentrations in the solution were determined using an inductively coupled plasma optical emission spectrophotometer (ICP-OES). For quality control, all samples were run in duplicate with blanks and a certified National Institute of Standards and Technology (NIST) standard (Buffalo River sediment 2704, National Institute of Standards and Technology Gaithersburg, MD) included after every 10 samples (Hirpassa and Codling 2019). Analysis of variance was used to determine statistically significant differences among treatments (SAS 2012). Separation of means was performed using Duncan's multiple range test at $\mathrm{P} \leq 0.05$ (Steel and Torrie 1980).

\section{Results and discussion}

\section{New Jersey}

The New Jersey study sites were six agricultural fields that had received single applications of biosolids between 1996 and 2001 (Table 1) prior to being sampled for this study in 2017 . Soil $\mathrm{pH}$ in the $0-15 \mathrm{~cm}$ depth ranged from 5.46 at the Gloucester-E site to 7.87 at the Salem site (Table 3). Soil pH changed significantly with increasing soil depth only for the Harrison (+0.78 unit) and Sayreville (-1.61 unit)

Table 3. Soil pH, electrical conductivity, and concentrations of $\mathrm{C}, \mathrm{Cd}, \mathrm{Cu}, \mathrm{Pb}$ and $\mathrm{Zn}$ in soils collected from biosolids-amended fields in New Jersey.

\begin{tabular}{|c|c|c|c|c|c|c|c|c|}
\hline \multirow[t]{2}{*}{ Sites } & \multirow[t]{2}{*}{ Depth } & \multirow[t]{2}{*}{$\mathrm{pH}$} & \multirow{2}{*}{$\begin{array}{c}\mathrm{EC} \\
\mu \mathrm{S} \mathrm{cm}^{-1}\end{array}$} & \multirow{2}{*}{$\begin{array}{c}\mathrm{C} \\
\mathrm{g} \mathrm{kg}^{-1}\end{array}$} & $\mathrm{Cd}$ & $\mathrm{Cu}$ & $\mathrm{Pb}$ & $\mathrm{Zn}$ \\
\hline & & & & & \multicolumn{4}{|c|}{$-----------\mathrm{mg} \mathrm{kg}^{-1}------------$} \\
\hline \multirow[t]{2}{*}{ Hunterdon } & $0-15$ & $6.92 \mathrm{bct}$ & $69.9 \mathrm{~d}$ & 16.6 ef & $3.79 \mathrm{a}$ & $18.2 \mathrm{C}$ & $24.3 \mathrm{c}$ & $95.3 \mathrm{C}$ \\
\hline & $15-30$ & $6.40 \mathrm{c}$ & $35.3 d$ & $8.9 \mathrm{f}$ & $3.62 \mathrm{a}$ & $18.0 \mathrm{C}$ & $23.6 \mathrm{c}$ & $95.0 \mathrm{C}$ \\
\hline \multirow[t]{2}{*}{ Salem } & $0-15$ & $7.87 \mathrm{a}$ & $203 c$ & $90.0 \mathrm{a}$ & $1.94 \mathrm{C}$ & $54.1 \mathrm{a}$ & $23.7 \mathrm{c}$ & $207 \mathrm{a}$ \\
\hline & $15-30$ & $7.81 \mathrm{a}$ & $186 \mathrm{c}$ & $74.0 \mathrm{~b}$ & $1.66 \mathrm{c}$ & $51.8 \mathrm{a}$ & $18.0 \mathrm{~cd}$ & $149 \mathrm{~b}$ \\
\hline \multirow[t]{2}{*}{ Gloucester-E } & $0-15$ & $5.46 \mathrm{~d}$ & $80.5 \mathrm{~d}$ & $29.0 \mathrm{~cd}$ & $0.81 \mathrm{~d}$ & $8.7 \mathrm{de}$ & $18.2 \mathrm{~cd}$ & $27.5 \mathrm{f}$ \\
\hline & $15-30$ & $5.66 \mathrm{~d}$ & $81.5 \mathrm{~d}$ & 17.9 ef & $0.81 \mathrm{~d}$ & $6.2 \mathrm{e}$ & $17.9 \mathrm{~cd}$ & $26.4 \mathrm{f}$ \\
\hline \multirow[t]{2}{*}{ Gloucester-H } & $0-15$ & $5.66 \mathrm{~d}$ & $50.2 \mathrm{~d}$ & 14.5 ef & $1.58 \mathrm{C}$ & $15.4 \mathrm{~cd}$ & $15.2 \mathrm{~d}$ & 39.6 ef \\
\hline & $15-30$ & $6.44 c$ & $39.7 \mathrm{~d}$ & $10.9 \mathrm{f}$ & $1.73 \mathrm{C}$ & 10.4 c-e & 13.7 de & $41.0 \mathrm{~d}-\mathrm{f}$ \\
\hline \multirow{2}{*}{ Middlesex } & $0-15$ & $7.08 \mathrm{~b}$ & $234 \mathrm{bc}$ & $25.8 \mathrm{~cd}$ & $0.76 \mathrm{~d}$ & $18.5 \mathrm{c}$ & $14.8 \mathrm{de}$ & 30.7 ef \\
\hline & $15-30$ & $5.47 \mathrm{~d}$ & $163 \mathrm{c}$ & $10.3 \mathrm{f}$ & $0.98 \mathrm{~d}$ & $12.8 \mathrm{c}-\mathrm{e}$ & $8.6 \mathrm{e}$ & $20.4 \mathrm{f}$ \\
\hline \multirow[t]{2}{*}{ Monmouth } & $0-15$ & $7.33 a b$ & $402 \mathrm{a}$ & $32.5 \mathrm{c}$ & $2.42 \mathrm{~b}$ & $32.8 \mathrm{~b}$ & $53.9 \mathrm{~b}$ & 58.3 de \\
\hline & $15-30$ & $7.33 a b$ & $286 \mathrm{~b}$ & $31.2 c$ & $2.89 \mathrm{~b}$ & $28.0 \mathrm{~b}$ & $72.3 \mathrm{a}$ & $70.0 \mathrm{~cd}$ \\
\hline
\end{tabular}

† Within columns, treatment means having letters in common are not significantly different at $P \leq 0.05$. 
sites. Soil EC in the $0-15 \mathrm{~cm}$ depth ranged from 50.2 at the Harrison site to $402 \mu \mathrm{S} \mathrm{cm}^{-1}$ at the Monmouth site, where it declined significantly with increasing soil depth. The Monmouth site was located within the cloverleaf ramp of a major highway and may have been affected by road salt. Additionally, the biosolids applied to New Jersey soils were treated with lime kiln dust and quicklime $(\mathrm{CaO})$ which increased the EC content of the biosolids and appeared to be reflected in the two sites with high application rates in Monmouth \& Middlesex sites. Soil Total Carbon (TC) concentration for both the surface and subsurface depths was highest at the Salem site. There was a trend of decreased TC concentration with increasing soil depth, which was significant for the Salem, Gloucester-E and Middlesex sites. Averaged over soil depth, soil Cd concentration ranged from $0.81 \mathrm{mg} \mathrm{kg}^{-1}$ at the Gloucester-E site to $3.71 \mathrm{mg} \mathrm{kg}^{-1}$ at the Hunterdon site. In all cases, soil Cd levels were below the $39 \mathrm{mg} \mathrm{kg}^{-1}$ limit that requires notification before Cd-contaminated soil can be released for other uses. The Hunterdon and Monmouth sites had Cd concentrations that were considered safe for residential use (Sonon and Gaskin 2009) and all the elements measured had levels below what could be suitable for home gardens as stipulated under the US. EPA 40 Code of Federal Regulations (CFR) Part 503.13. Soil Cd concentration was not significantly affected by soil depth. The variations observed in $\mathrm{Cd}$ concentration between sites may have been due to variations in the composition of the applied biosolids. According to Silveira, Alleoni, and Guilherme (2003), biosolids obtained from domestic sources have lower levels of heavy metals compared to those with significant contamination from industrial sources. Soil $\mathrm{Cu}$ concentration in the surface layer ranged from $8.67 \mathrm{mg} \mathrm{kg}^{-1}$ at the Gloucester-E site to $54.1 \mathrm{mg} \mathrm{kg}^{-1}$ at the Salem site, a value significantly higher than those of the other sites. There was a trend of decreased soil $\mathrm{Cu}$ concentration with increased soil depth, but differences were not significant. Soil $\mathrm{Pb}$ concentration, averaged over soil depth, ranged from $11.7 \mathrm{mg}$ $\mathrm{kg}^{-1}$ at the Middlesex site to $63.1 \mathrm{mg} \mathrm{kg}^{-1}$ at the Monmouth site. The significantly higher $\mathrm{Pb}$ concentration at the Monmouth site relative to the other sites may have been due to residual $\mathrm{Pb}$ from the use of leaded gasoline, as this site was in a cloverleaf ramp near a major highway. Wuana and Okieimen (2011) stated that $\mathrm{Pb}$ from leaded gasoline can elevate $\mathrm{Pb}$ levels in soil along roadways. In all cases, $\mathrm{Pb}$ levels were below the value $\left(75 \mathrm{mg} \mathrm{kg}^{-1}\right)$ considered safe for residential use (Sonon and Gaskin 2009). Soil Zn concentration in the surface layer ranged from $27.5 \mathrm{mg} \mathrm{kg}^{-1}$ at the Gloucester-E site to $207 \mathrm{mg} \mathrm{kg}^{-1}$ at the Salem site. The latter value, although significantly higher than those of the other sites, was nevertheless below the release notification concentration limit of $2800 \mathrm{mg} \mathrm{kg}^{-1}$ (U.S. Environmental Protection Agency 1993; U.S. Environmental Protection Agency 1995). This was also indicated in a general public safety guideline for home or public gardens where the safe levels were shown under heavy metals and gardens. Except for the Salem site, soil Zn did not vary significantly with soil depth. Averaged over sites, $\mathrm{pH}, \mathrm{EC}$, and soil $\mathrm{C}$ and $\mathrm{Cu}$ concentrations were significantly higher in the 0-15 cm depth compared to the $15-30 \mathrm{~cm}$ depth, whereas soil $\mathrm{Cd}, \mathrm{Pb}$ and $\mathrm{Zn}$ concentrations were not significantly affected by soil depth (Table 4 ).

\section{Virginia}

At the two Virginia study sites, soil samples were collected in 2017 from plots of two agronomic experiments. At Location I, treatments were applied for 4 years (2000, 2002-2004) and consisted of biosolids compost (BC), biosolids compost + fertilizer (BCF), and a fertilizer control. At Location II, five rates of biosolids, including a zero-biosolids fertilized control, were applied in 1996.

Table 4. Soil pH, electrical conductivity, and concentrations of $\mathrm{C}, \mathrm{Cd}, \mathrm{Cu}, \mathrm{Pb}$ and $\mathrm{Zn}$ in soils collected from biosolids-amended fields in New Jersey, averaged over soil depth.

\begin{tabular}{|c|c|c|c|c|c|c|c|}
\hline \multirow{2}{*}{$\begin{array}{l}\text { Depth } \\
\mathrm{cm}\end{array}$} & \multirow{2}{*}{$\mathrm{pH}$} & \multirow{2}{*}{$\begin{array}{c}\mathrm{EC} \\
\mu \mathrm{S} \mathrm{cm}^{-1}\end{array}$} & \multirow{2}{*}{$\begin{array}{c}\mathrm{C} \\
\mathrm{gkg}^{-1}\end{array}$} & $\mathrm{Cd}$ & $\mathrm{Cu}$ & $\mathrm{Pb}$ & $\mathrm{Zn}$ \\
\hline & & & & \multicolumn{4}{|c|}{$---------------\mathrm{mg} \mathrm{kg}^{-1}--------------$} \\
\hline $0-15$ & 6.74 at & $139 a$ & $30.6 \mathrm{a}$ & $2.05 \mathrm{a}$ & $22 \mathrm{a}$ & $21 a$ & $77 a$ \\
\hline $15-30$ & $6.39 \mathrm{~b}$ & $105 \mathrm{~b}$ & $20.6 \mathrm{~b}$ & $2.08 \mathrm{a}$ & $19 \mathrm{~b}$ & $19 \mathrm{a}$ & $68 \mathrm{a}$ \\
\hline
\end{tabular}

+ Within columns, treatment means having letters in common are not significantly different at $P \leq 0.05$. 


\section{Location I}

Apart from the 15-30 cm depth of the BCF treatment, there was no significant difference in soil $\mathrm{pH}$ between the control and biosolids-amended treatments at Location I (Table 5). Soil pH also did not change with increasing soil depth. This might be due to the decomposition and cycling or use of the amendments. At each soil depth, soil EC did not differ significantly between the biosolids and control treatments, but EC decreased significantly with increasing depth for all treatments. At each soil depth, soil $\mathrm{C}$ concentration in the biosolids-amended treatments was greater than or equal to those of the control. Spargo, Evanylo, and Alley (2006) observed higher levels of soil C in these same plots in 2004. This decline in soil C concentration over time may have resulted from loss of $\mathrm{C}$ due to limited return of biomass to the soil from the types of crops grown at this site (Evanylo and Sherony 2002) as well as normal C mineralization. The Soil C concentration was slightly higher at the $0-15 \mathrm{~cm}$ depth when compared to the 15-30 cm depth and compares to the research results of (Li and Evanylo 2013). Soil $\mathrm{Cd}$ levels at this site were below the instrument detection limit, so no $\mathrm{Cd}$ data is presented. Soil $\mathrm{Cu}, \mathrm{Pb}$ and $\mathrm{Zn}$ concentrations at this site were not significantly influenced by biosolids application. Averaged over soil depth, soil $\mathrm{pH}, \mathrm{EC}$ and $\mathrm{C}$ differed significantly from the control only in the BCF treatment, which had higher values of all three variables (Table 6).

\section{Location II}

At Location II, soil $\mathrm{pH}$ at the $0-15 \mathrm{~cm}$ depth did not differ significantly between the biosolids-amended and control treatments, and neither was the soil $\mathrm{pH}$ significantly affected by soil depth (Table 7). At each soil depth, soil EC in the biosolids treatments was greater than or equal to the control value. Except at the highest biosolids rate (7xBS), soil EC decreased with increased soil depth. This was not considered an important variable to logically predict the behavior of biosolids long term application effects. This is because EC is very temporal, typically elevated in the spring/summer shortly after application of soluble fertilizer and reduced in late winter/early spring following winter leaching rainfall. Soil C concentration decreased with increased soil depth for all treatments. Soil Cd levels at this site were below the instrument detection limit, so no Cd data is presented. At the $0-15 \mathrm{~cm}$ depth, there was a trend of lower soil $\mathrm{Cu}$ concentration in the biosolids treatments compared to the control, but at the lower soil depth there were no significant differences among treatments. There was a trend of decreased soil $\mathrm{Cu}$ with increased depth. Soil $\mathrm{Pb}$ concentration at both depths did not differ significantly between the biosolids and control treatments. Soil $\mathrm{Pb}$ was significantly affected by soil depth only in the $3 x B S$ treatment, where it was higher at the lower depth. Soil Zn concentration at each soil depth was not significantly affected by biosolids addition but it decreased with increased soil depth in all treatments. Averaged over soil depth, biosolids addition at all rates did not significantly affect soil $\mathrm{pH}$ and EC (Table 8). Soil C concentration in the biosolids treatments differed from the control only in the $5 \mathrm{xBS}$ treatment, which had a slightly higher value. Soil $\mathrm{Cu}$ concentration was lower in the biosolids treatments compared to the control. Soil $\mathrm{Pb}$ concentration was not significantly influenced by biosolids application. Soil $\mathrm{Zn}$ concentration in the biosolids treatments was less than or equal to the

Table 5. Soil pH, electrical conductivity, and concentrations of $\mathrm{C}, \mathrm{Cu}, \mathrm{Pb}$ and $\mathrm{Zn}$ in soils collected from biosolids-amended fields at Location I in Virginia.

\begin{tabular}{|c|c|c|c|c|c|c|c|}
\hline \multirow{2}{*}{ Treatment } & \multirow{2}{*}{ Depth } & \multirow{2}{*}{$\mathrm{pH}$} & \multirow{2}{*}{$\begin{array}{c}\mathrm{EC} \\
\mu \mathrm{Scm}^{-1}\end{array}$} & \multirow{2}{*}{$\begin{array}{c}\mathrm{C} \\
\mathrm{g} \mathrm{kg}^{-1}\end{array}$} & $\mathrm{Cu}$ & $\mathrm{Pb}$ & $\mathrm{Zn}$ \\
\hline & & & & & \multicolumn{3}{|c|}{$---------\mathrm{mg} \mathrm{kg}^{-1}---------$} \\
\hline \multirow{2}{*}{ Control } & $0-15$ & $5.93 \mathrm{bt}$ & $112 \mathrm{a}$ & $19.4 \mathrm{~b}$ & $36.4 \mathrm{a}$ & $8.81 \mathrm{a}$ & $44.6 \mathrm{a}$ \\
\hline & $15-30$ & $5.91 \mathrm{~b}$ & $62 c$ & $12.8 \mathrm{c}$ & $34.6 \mathrm{a}$ & $8.61 \mathrm{a}$ & $44.5 \mathrm{a}$ \\
\hline \multirow[t]{2}{*}{ BC } & $0-15$ & $6.21 \mathrm{ab}$ & $105 \mathrm{~b}$ & $20.1 \mathrm{~b}$ & $36.1 \mathrm{a}$ & $8.45 \mathrm{a}$ & $49.7 \mathrm{a}$ \\
\hline & $15-30$ & $6.14 \mathrm{ab}$ & $60 c$ & $19.4 \mathrm{~b}$ & $35.3 \mathrm{a}$ & $8.17 \mathrm{a}$ & $44.5 \mathrm{a}$ \\
\hline \multirow[t]{2}{*}{$\mathrm{BCF}$} & $0-15$ & $6.26 \mathrm{ab}$ & $113 \mathrm{a}$ & $27.8 \mathrm{a}$ & $39.7 \mathrm{a}$ & $9.53 \mathrm{a}$ & $46.2 \mathrm{a}$ \\
\hline & $15-30$ & $6.36 \mathrm{a}$ & $75 c$ & $12.9 \mathrm{C}$ & $35.3 \mathrm{a}$ & $8.73 \mathrm{a}$ & $44.5 \mathrm{a}$ \\
\hline
\end{tabular}

† Within columns, treatment means having letters in common are not significantly different at $P \leq 0.05$.

$\mathrm{BC}=$ biosolids compost, $\mathrm{BCF}=$ biosolids compost + fertilizer. 
Table 6. Soil pH, electrical conductivity, and concentrations of $\mathrm{C}, \mathrm{Cu}, \mathrm{Pb}$ and $\mathrm{Zn}$ in soils collected from biosolids-amended fields at Location I in Virginia, averaged over soil depth.

\begin{tabular}{|c|c|c|c|c|c|c|}
\hline \multirow{2}{*}{ Treatment } & \multirow{2}{*}{$\mathrm{pH}$} & \multirow{2}{*}{$\begin{array}{c}\mathrm{EC} \\
\mu \mathrm{Scm}^{-1}\end{array}$} & \multirow{2}{*}{$\begin{array}{c}\mathrm{C} \\
\mathrm{g} \mathrm{kg}^{-1}\end{array}$} & $\mathrm{Cu}$ & $\mathrm{Pb}$ & $\mathrm{Zn}$ \\
\hline & & & & \multicolumn{3}{|c|}{$-------------\mathrm{mg} \mathrm{kg}^{-1}------$} \\
\hline Control & $5.92 \mathrm{bt}$ & $87.5 \mathrm{~b}$ & $16.1 \mathrm{~b}$ & $35.5 \mathrm{a}$ & $8.71 \mathrm{a}$ & $44.6 \mathrm{a}$ \\
\hline$B C$ & $6.18 \mathrm{ab}$ & $82.5 \mathrm{~b}$ & $15.9 \mathrm{~b}$ & $35.7 \mathrm{a}$ & $8.31 \mathrm{a}$ & $45.3 \mathrm{a}$ \\
\hline $\mathrm{BCF}$ & $6.31 \mathrm{a}$ & $105 a$ & $20.4 \mathrm{a}$ & $37.7 \mathrm{a}$ & $9.13 \mathrm{a}$ & $47.1 \mathrm{a}$ \\
\hline
\end{tabular}

† Within columns, treatment means having letters in common are not significantly different at $P \leq 0.05$.

$\mathrm{BC}=$ biosolids compost, $\mathrm{BCF}=$ biosolids compost + fertilizer.

Table 7. Soil pH, electrical conductivity, and concentrations of $\mathrm{C}, \mathrm{Cu}, \mathrm{Pb}$ and $\mathrm{Zn}$ in soils collected from biosolids-amended fields at Location II in Virginia.

\begin{tabular}{|c|c|c|c|c|c|c|c|}
\hline \multirow[t]{2}{*}{ Treatment } & \multirow{2}{*}{$\begin{array}{c}\text { Depth } \\
\mathrm{cm}\end{array}$} & \multirow[t]{2}{*}{$\mathrm{pH}$} & \multirow{2}{*}{$\begin{array}{c}E C \\
\mu S / c m\end{array}$} & \multirow{2}{*}{$\begin{array}{c}\mathrm{C} \\
\mathrm{g} \mathrm{kg}^{-1}\end{array}$} & $\mathrm{Cu}$ & $\mathrm{Pb}$ & $\mathrm{Zn}$ \\
\hline & & & & & \multicolumn{3}{|c|}{$-------------\mathrm{mg} \mathrm{kg}^{-1}------$} \\
\hline FC & $0-15$ & $5.93 \mathrm{a}-\mathrm{ct}$ & $85 \mathrm{~b}-\mathrm{d}$ & $13.8 \mathrm{a}$ & $12.4 \mathrm{a}$ & $16.8 \mathrm{ab}$ & $62.7 \mathrm{a}$ \\
\hline FC & $15-30$ & $6.15 \mathrm{ab}$ & 67 ef & $7.1 \mathrm{de}$ & 8.0 b-e & $17.2 \mathrm{ab}$ & $50.2 \mathrm{~b}$ \\
\hline $1 \times B S$ & $0-15$ & $5.93 \mathrm{a}-\mathrm{c}$ & $88 a b$ & $14.2 \mathrm{a}$ & $9.3 \mathrm{bc}$ & $16.2 \mathrm{ab}$ & $64.7 \mathrm{a}$ \\
\hline $1 \times B S$ & $15-30$ & $5.96 a b$ & 67 ef & $8.2 \mathrm{~cd}$ & $7.1 \mathrm{de}$ & $18.8 \mathrm{ab}$ & $46.6 \mathrm{~b}$ \\
\hline $3 \times B S$ & $0-15$ & $6.13 a b$ & $95 \mathrm{a}$ & $14.0 \mathrm{a}$ & $8.9 \mathrm{~b}-\mathrm{d}$ & $15.6 \mathrm{~b}$ & $51.8 \mathrm{a}$ \\
\hline $3 \times B S$ & $15-30$ & $6.19 \mathrm{a}$ & $63 \mathrm{f}$ & $8.5 \mathrm{c}$ & $6.9 \mathrm{de}$ & $21.9 \mathrm{a}$ & $41.8 \mathrm{~b}$ \\
\hline $5 \times B S$ & $0-15$ & 5.89 b-d & $87 \mathrm{a}$ & $14.1 \mathrm{a}$ & $7.1 \mathrm{de}$ & $15.8 \mathrm{~b}$ & $61.0 \mathrm{a}$ \\
\hline $5 \times B S$ & $15-30$ & 5.99 b-d & $63 \mathrm{f}$ & $9.2 \mathrm{c}$ & $6.4 \mathrm{e}$ & $20.1 \mathrm{ab}$ & $40.7 \mathrm{~b}$ \\
\hline $7 \times B S$ & $0-15$ & $5.73 \mathrm{~cd}$ & 77 c-e & $12.2 \mathrm{~b}$ & $10.3 a b$ & $16.1 \mathrm{ab}$ & $65.4 \mathrm{a}$ \\
\hline $7 \times B S$ & $15-30$ & $5.62 \mathrm{~d}$ & $75 \mathrm{de}$ & $6.90 \mathrm{e}$ & 7.7 c-d & $18.8 \mathrm{ab}$ & $46.8 \mathrm{~b}$ \\
\hline
\end{tabular}

† Within columns, treatment means having letters in common are not significantly different at $P \leq 0.05$.

$\mathrm{FC}=$ fertilized control, $\mathrm{BS}=$ biosolids.

control value. These results might signify the mineralization as well as the nutrient and biogeochemical cycling of these nutrients and metals.

\section{Conclusions}

Soil $\mathrm{pH}$ and EC values in biosolids-amended soils from two regions in the United States varied between locations and sites but were within the normal ranges for crop production. The levels of residual carbon and heavy metals remaining in the studied soils also varied with locations and application rates. The metal levels range from 0.76 to $3.79,8.7$ to $54.1,15.2$ to 53.9 , and 26 to $207 \mathrm{mg} \mathrm{kg}^{-1}$ for $\mathrm{Cd}, \mathrm{Cu}, \mathrm{Pb}$ and $\mathrm{Zn}$ respectively, as well as having carbon levels ranging from 14.5 to $90.0 \mathrm{~g} \mathrm{~kg}^{-1}$. The carbon levels were not consistent, as different sites received different levels of biosolids, but all the carbon levels were within the allowable limits. Generally, several accounts of biosolids research in different locations nationally, have a consistent conclusion of trace metals concentration and in some cases, possible downward movement in relation to the duration and levels

Table 8. Soil pH, electrical conductivity, and concentrations of $\mathrm{C}, \mathrm{Cu}, \mathrm{Pb}$ and $\mathrm{Zn}$ in soils collected from biosolids-amended fields at Location II in Virginia, averaged over soil depth.

\begin{tabular}{|c|c|c|c|c|c|c|}
\hline \multirow{2}{*}{ Treatments } & \multirow{2}{*}{$\mathrm{pH}$} & \multirow{2}{*}{$\begin{array}{c}E C \\
\mu S / c m\end{array}$} & \multirow{2}{*}{$\begin{array}{c}\mathrm{C} \\
\mathrm{g} \mathrm{kg}^{-1}\end{array}$} & $\mathrm{Cu}$ & $\mathrm{Pb}$ & $\mathrm{Zn}$ \\
\hline & & & & \multicolumn{3}{|c|}{$--------\mathrm{mg} \mathrm{kg}^{-1}---------$} \\
\hline FC & $6.04 \mathrm{abt}$ & $76.2 \mathrm{a}$ & $10.4 \mathrm{bc}$ & $10.1 \mathrm{a}$ & $17.0 \mathrm{a}$ & $56.0 \mathrm{a}$ \\
\hline $1 \times B S$ & $5.94 \mathrm{~b}$ & $78.0 \mathrm{a}$ & $11.2 \mathrm{ab}$ & $8.4 b c$ & $17.5 \mathrm{a}$ & $55.7 \mathrm{a}$ \\
\hline $3 \times B S$ & $6.16 \mathrm{a}$ & $79.6 \mathrm{a}$ & $11.3 \mathrm{ab}$ & $7.9 \mathrm{c}$ & $18.7 \mathrm{a}$ & $50.8 \mathrm{~b}$ \\
\hline $5 \times B S$ & $5.89 \mathrm{a}$ & $75.0 \mathrm{a}$ & $11.7 \mathrm{a}$ & $6.8 \mathrm{~d}$ & $17.9 \mathrm{a}$ & $51.0 \mathrm{~b}$ \\
\hline $7 \times B S$ & $5.68 \mathrm{a}$ & $75.8 \mathrm{a}$ & $9.6 \mathrm{c}$ & $9.0 \mathrm{~b}$ & $18.3 \mathrm{a}$ & $56.1 \mathrm{a}$ \\
\hline
\end{tabular}

$\dagger$ Within columns, treatment means having letters in common are not significantly different at $P \leq 0.05$.

$\mathrm{FC}=$ fertilized control, $\mathrm{BS}=$ biosolids. 
of applications, but do not necessarily affect their use because the metal concentrations are all below the standards in 40 CFR Part 503. Therefore, the concentration of metals in soils amended with biosolids will primarily depend on the rate and duration of applications as well as the type of crop/ plant that would facilitate the biogeochemical cycling and turnover within that site.

\section{Acknowledgments}

The authors wish to thank Mr. Andrew Russ, Mr. Alex White and Mr. Darryl Baxam for assisting in soil sample collection. They also wish to thank Ms. Mebrat Gesese for analysis of the soil samples.

\section{References}

Barbarick, K. A., A. J. Ippolito, and D. G. Wesfall. 1998. Extractable trace elements in the soil profile after years of biosolids application. Journal of Environmental Quality 27 (4):801-05. doi:10.2134/jeq1998.00472425002700040012x.

Brown, S., R. L. Chaney, J. G. Hallfrisch, and Q. Xue. 2003. Effect of biosolids processing on lead bioavailability in an urban soil. Journal of Environmental Quality 32 (1):100-08. doi:10.2134/jeq2003.1000.

Brown, S., K. Kurtz, A. Bary, and C. Cogger. 2011. Quantifying Benefits Associated with land application of organic residuals in Washington State. Environmental Science \& Technology 45 (17):7451-58. doi:10.1021/es2010418.

Codling, E. E. 2014. Long-term effects of biosolids-amended soils on phosphorus, copper, manganese and zinc uptake by wheat. Soil Science 179 (1):21-27. doi:10.1097/SS.0000000000000041.

Codling, E. E., and B. Eickhoff. 2012. Distribution of plant nutrient elements and carbon in particle size fractions of broiler litter ash. The Open Agriculture Journal 6 (1):48-52. doi:10.2174/1874331501307010048.

Daniels, W. L., G. K. Evanylo, S. M. Nagle, and J. M. Schmidt. 2001. Effects of biosolids loading rate and sawdust additions on row crop yield and nitrate leaching potentials in Virginia sand and gravel mine reclamation. 2001 National Meeting of the American Society of Surface Mine Reclamation, Albuquerque, New Mexico, June 3- 7, 2001.

Evanylo, G. K., C. Sherony, J. Spargo, D. Starner, M. Brosius, and K. Haering. 2008. Soil and water environmental effects of fertilizer- manure -, and compost- based fertility practices in organic vegetables cropping system. Agriculture, Ecosystems \& Environment 127 (1-2):50-58. doi:10.1016/j.agee.2008.02.014.

Evanylo, G. K., and C. A. Sherony. 2002. Agronomic and environmental effects of compost, manure and fertilizer use. P. 730-740. In 2002 International Symposium: Composting and Compost Utilization, Columbus, $\mathrm{OH}$, May 6-8.

Gaskin, J. W., R. B. Brobst, W. P. Miller, and E. W. Tollner. 2003. Long-term biosolids application effects on metal concentrations in soil and bermudagrass forage. Journal of Environmental Quality 32 (1):146-52. doi:10.2134/ jeq2003.1460.

Granato, T. C., R. I. Pitz, G. A. Knafl, C. R. Carlson Jr., P. Tata, and C. Lue-Hing. 2004. Trace element concentrations in soil, corn leaves, and grain after cessation of biosolids applications. Journal of Environmental Quality 33 (6):2078-89. doi:10.2134/jeq2004.2078.

Hirpassa, W. D., and E. E. Codling. 2019. Growth and metal uptake of lettuce [lactuca Sativa L] on soil amended with biosolids and gypsum. Communication in Soil Science and Plant Analysis 50 (16):2033-40. doi:10.1080/ 00103624.2019 .1648662$.

Hreiz, R., M. A. Latifi, and N. Roche. 2015. Optimal design and operation of activated sludge processes: State-of-the-art. Chemical Engineering Journal 281:900-20. doi:10.1016/j.cej.2015.06.125.

Li, J., and G. K. Evanylo. 2013. The effects of long-term application of organic amendments on soil organic carbon accumulation. Soil Science Society of America Journal 77 (3):964-73. doi:10.2136/sssaj2012.0306.

McGrath, S. P., and C. H. Cunliffe. 1985. A simplified method for the extraction of the metals $\mathrm{Fe}, \mathrm{Zn}, \mathrm{Cu}, \mathrm{Ni}, \mathrm{Cd}, \mathrm{Pb}, \mathrm{Cr}$, Co and Mn from soils and sewage sludges. Journal of Science Food and Agriculture 36 (9):794-98. doi:10.1002/ jsfa.2740360906.

Moffet, C. A., R. E. Zartman, D. B. Wester, and R. E. Sosebee. 2005. Surface biosolids application: effects on infiltration, erosion, and soil organic carbon in Chihuahuan desert grasslands and shrublands. Journal of Environmental Quality 34 (1):299-311. doi:10.2134/jeq2005.0299.

Mossa, A.-W., E. H. Bailey, A. Usman, S. D. Young, and N. M. J. Crout. 2020. The impact of long-term biosolids application (>100 years) on soil metal dynamics. Science of the Total Environment 720:137441. doi:10.1016/j. scitotenv.2020.137441.

Oladeji, O. O., G. Tian, A. E. Cox, T. C. Granato, R. I. Pietz, C. R. Carlson, and Z. Abedin. 2012. Effects of long-term application of biosolids for mine land reclamation on groundwater chemistry: Trace metals. Journal of Environmental Quality 41 (5):1445-51. doi:10.2134/jeq2011.0472.

SAS. 2012. SAS, proc mixed. 9.4 ed. Cary, NC: SAS Institute.

Sharma, B., A. Sarkar, P. Singh, and R. P. Singh. 2017. Agricultural utilization of biosolids: A review on potential effects on soil and plant grown. Waste Management 64:117-32. doi:10.1016/j.wasman.2017.03.002. 
Silveira, M. L. A., L. R. F. Alleoni, and L. R. G. Guilherme. 2003. Biosolids and heavy metals in soils. Science Agriculture (Piracicaba, Braz.) 60 (4). doi: 10.1590/s0103-90162003000400029.

Sloan, J. J., R. H. Dowdy, and M. S. Dolan. 1998. Recovery of biosolids-applied heavy metals sixteen years after application. Journal of Environmental Quality 27 (6):1312-17. doi:10.2134/jeq1998.00472425002700060007x.

Sonon, L. S., and J. Gaskin. 2009. Metal concentration standards for land application of biosolids and other by-products in Georgia. University of Georgia Cooperative Extension. Bulletin 1353.

Spargo, J. T., G. K. Evanylo, and M. M. Alley. 2006. Repeated compost application effects on phosphorus runoff in the virginia piedmont. Journal of Environmental Quality 35 (6):2342-51. doi:10.2134/jeq2006.0105.

Steel, R. G. D., and J. H. Torrie. 1980. Duncan's new multiple range test. principles and procedures of statistic, $187-88$. New York: McGraw-Hill.

Sukkariyah, B. F., G. Evanylo, L. Zelazny, and R. L. Chaney. 2005a. Recovery and distribution of biosolids-derived trace metals in a clay loam soil. Journal of Environmental Quality 34 (5):1843-50. doi:10.2134/jeq2004.0180.

Sukkariyah, B. F., G. Evanylo, L. Zelazny, and R. L. Chaney. 2005b. Cadmium, copper, nickel, and zinc availability in a biosolids-amended piedmont soil years after application. Journal of Environmental Quality 34 (6):2255-62. doi:10.2134/jeq2004.0369.

U.S. Environmental Protection Agency. 1993. Standards for the use and disposal of sewage sludge. $40 \mathrm{CFR}$, Part 503. Federal Registration 58: 9248-415.

U.S. Environmental Protection Agency. 1995. A guide to the biosolids risk assessment for the EPA Part 503 rule. USEPA Rep. 823/B-93/005. Washington, DC: USEPA.

Wang, H., S. L. Brown, G. N. Magesan, A. H. Slade, M. Quintern, P. W. Clinton, and T. W. Payn. 2008. Technological options for the management of biosolids. Environmental Science and Pollution Research - International 15 (4):308-17. doi:10.1007/s11356-008-0012-5.

Wijesekara, H., N. S. Bolan, R. Thangavel, B. Seshadri, A. Surapaneni, C. Saint, C. Hetherington, P. Matthews, and M. Vithanage. 2017. The impact of biosolids application on organic carbon and carbon dioxide fluxes in soil. Chemosphere 85:86-93. doi:10.1016/j.chemosphere.2017.09.090.

Wuana, R., and F. E. Okieimen. 2011. Heavy metals in contaminated soils: A review of sources, chemistry, risks and best available strategies for remediation. International Scholarly Research Notices. doi:10.5402/2011/402647.

Wuest, S. B., and C. L. Reardon. 2016. Surface and root inputs produce different carbon/phosphorus ratios in soil. Soil Science Society of America Journal 80 (2):463-71. doi:10.2136/sssaj2015.09.0334.

Zartman, R. E., C. A. Moffet, D. B. Wester, R. E. Sosebee, E. B. Fish, and W. F. Jaynes. 2012. Influence of surface biosolids application on infiltration. Applied and Environmental Soil Science 2012. Article ID 642791:9. doi:10.1155/2012/ 642791.

Zhai, W., D. J. Moschandreas, G. Tian, D. Venkatesan, and K. E. Noll. 2014. Degradation rate model formulation to estimate soil carbon sequestration from repeated biosolids application. Soil Science Society of America Journal 78 (1):238-47. doi:10.2136/sssaj2013.05.0180. 